\title{
Shoulder-Pad Sign in a Case of Amyloidosis Associated with Myeloma
}

\author{
Myelom ile Illişkili Sistemik Amiloidoz OIgusunda Omuz-Yastığı Işareti
}

(D) Ceren Uzunoğlu11, (D) Tayfur Toptaş2, (D) Yıldız İpek², (D) Fatma Arıkan², (D) Fergün Yılmaz², (D) Tülin Tuğlular2

${ }_{1}^{1}$ Marmara University Training and Research Hospital, Clinic of Internal Disease, Istanbul, Turkey

2 Marmara University Training and Research Hospital, Clinic of Hematology, istanbul, Turkey

\section{To the Editor,}

A 78-year-old female was admitted with the complaints of multiple joint swellings that had progressed over 8 months, involving the shoulders, elbows, wrists, knees, and ankles. On physical examination, she had generalized edema. The tongue was enlarged. Joint examination revealed swelling and tenderness of the bilateral anterior parts of the shoulders, elbows, wrists, knees, and ankles (Figure 1).

Her complete blood count and calcium levels were as follows:

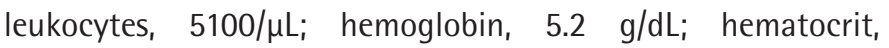
$16 \%$; platelets, $313,000 / \mu \mathrm{L}$; serum calcium, $11.9 \mathrm{mg} / \mathrm{dL}$. Serum total protein and albumin levels were $4.6 \mathrm{~g} / \mathrm{dL}$ and $3.0 \mathrm{~g} / \mathrm{dL}$, respectively. Serum free light chain kappa, lambda, and kappa/lambda ratio were $6792 \mathrm{mg} / \mathrm{L}, 7.31 \mathrm{mg} / \mathrm{L}$, and 929, respectively. Serum immunofixation electrophoresis was consistent with the kappa monoclonal band. Proteinuria (5 g) was identified upon 24-h urine analysis.

Bone marrow biopsy showed plasma cells infiltrating $86 \%$ of bone marrow (Figure 2). No lytic bone lesions were detected on positron emission tomography-computed tomography, but there were joint involvements compatible with inflammatory processes. Significant thickening of the subdeltoid bursa was evident upon shoulder magnetic resonance imaging (Figure 3). Bone marrow biopsy with Congo red staining revealed a green birefringent color representing amyloid deposition. A diagnosis of systemic amyloidosis associated with multiple myeloma was made.

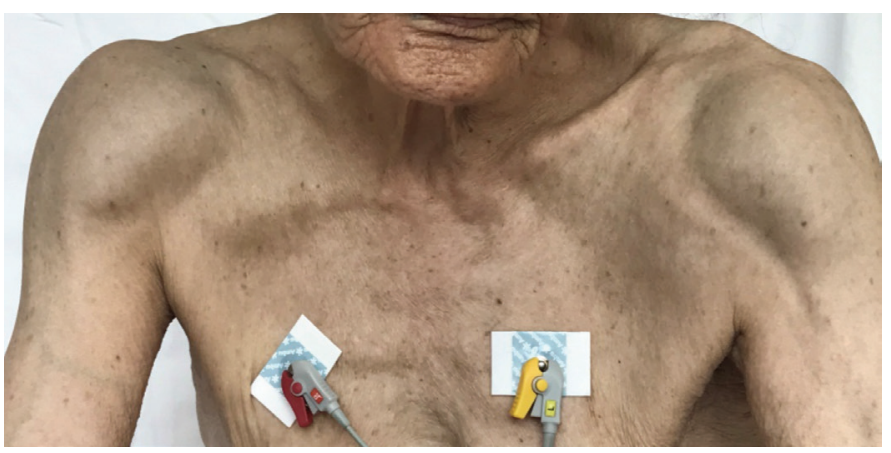

Figure 1. Joint examination revealed swelling and tenderness of the bilateral anterior parts of the shoulders, elbows, wrists, knees, and ankles.
"Shoulder-pad sign" is the prominent appearance of the bilateral anterior deltoid area. It is rare but suggestive for amyloid light-chain amyloidosis. It is mostly associated with the kappa light chain, which has a predilection for amyloid deposition in periarticular tissues [1].

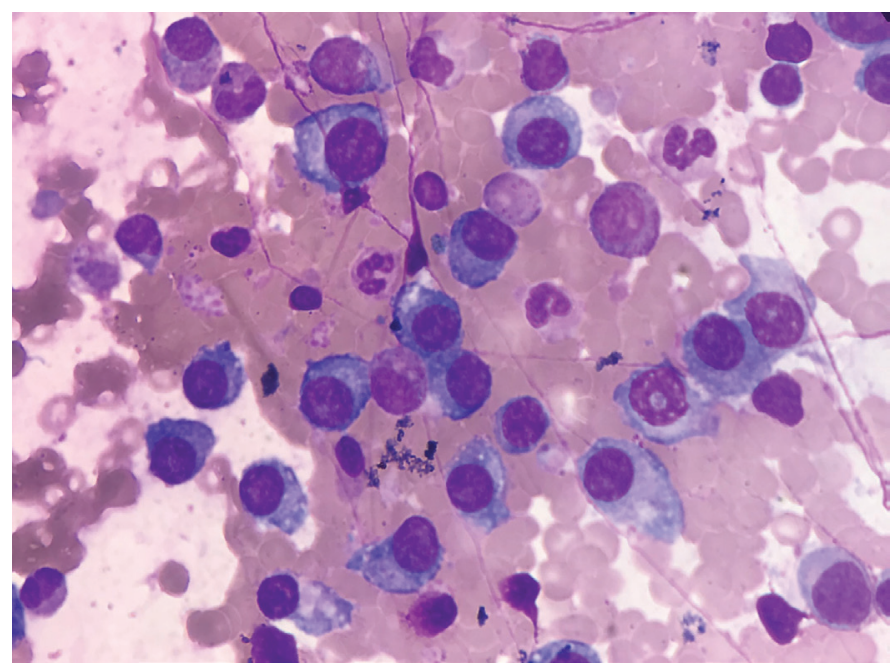

Figure 2. Bone marrow biopsy showed plasma cells infiltrating $86 \%$ of bone marrow.

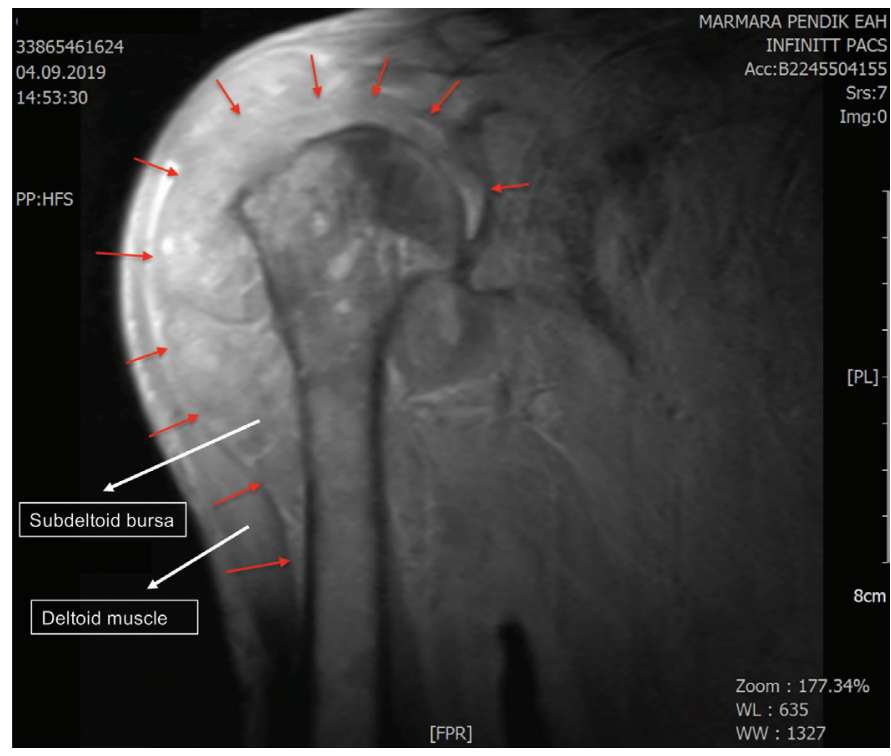

Figure 3. Significant thickening of the subdeltoid bursa was evident upon shoulder magnetic resonance imaging. 
In amyloidosis, joint or soft tissue involvement rarely occurs [2]. It was reported that 3.7\% of 191 patients with systemic amyloidosis had amyloid arthropathy and the shoulders were the most commonly affected joints [3]. Due to symmetrical joint involvement with pain, swelling, and limitation of movement, rheumatologic diseases might be considered in the differential diagnosis.

Keywords: Shoulder pad, Multiple myeloma, Kappa light chain, $\mathrm{AL}$ amyloidosis

Anahtar Sözcükler: Omuz yastığı, Multipl myelom, Kappa hafif zincir, AL amiloidoz

Informed Consent: Obtained.

\section{Authorship Contributions}

Concept: C.U., T.T., Y.I., F.A., F.Y., T.T.; Design: C.U., T.T., Y.I., F.A., F.Y., T.T.; Data Collection or Processing: C.U., T.T., Y.I., F.A., F.Y., T.T.; Analysis or Interpretation: C.U., T.T., Y.I., F.A., F.Y., T.T.;
Literature Search: C.U., T.T., Y.I., F.A., F.Y., T.T.; Writing: C.U., T.T., Y.I., F.A., F.Y., T.T.

Conflict of Interest: No conflict of interest was declared by the authors.

Financial Disclosure: The authors declared that this study received no financial support.

\section{References}

1. Liepnieks JJ, Burt C, Benson MD. Shoulder-pad sign of amyloidosis: structure of an Ig kappa III protein. Scand J Immunol 2001;54:404-408.

2. Gertz MA, Lacy MQ, Dispenzieri A, Buadi FK. Immunoglobulin light chain (AL) amyloidosis. In: Greer JP, Arber DA, Glader BE, List AF, Means RT Jr, Rodgers GM (eds). Wintrobe's Clinical Hematology, 14th Edition. Philadelphia, Wolters Kluwer, 2019.

3. Prokaeva T, Spencer B, Kaut M, Ozonoff A, Doros G, Connors LH, Skinner M, Seldin DC. Soft tissue, joint, and bone manifestations of AL amyloidosis: clinical presentation, molecular features, and survival. Arthritis Rheum 2007; $56: 3858-3868$

๑Copyright 2021 by Turkish Society of Hematology

Turkish Journal of Hematology, Published by Galenos Publishing House

\title{
Sweet Syndrome Associated with Ixazomib
}

\author{
İksazomib ile Illișili Sweet Sendromu
}

İrfan Yavaşoğlu, (D) Zahit Bolaman

Aydın Adnan Menderes University Faculty of Medicine, Department of Hematology, Aydın, Turkey

\section{To the Editor,}

A 69-year-old male patient was diagnosed with immunglobulin G-kappa chain type symptomatic multiple myeloma according to International Myeloma Working Group criteria (hemoglobin $9.8 \mathrm{~g} / \mathrm{dL}$, creatinine $1.5 \mathrm{mg} / \mathrm{dL}$ ). The case was categorized as Revised International Staging System (R-ISS) stage 2 [ $\beta 2$-microglobulin $4 \mathrm{mg} / \mathrm{L}$; high risk not detected by fluorescence in situ hybridization (FISH)], and because of the patient's renal failure, he was started on bortezomib-cyclophosphamidedexamethasone. After eight cycles (stem cell mobilization was performed after four cycles), peripheral blood stem cell transplantation with high-dose melphalan was performed with the patient in full remission. Lenalidomide and dexamethasone (lenalidomide $25 \mathrm{mg} /$ day, days 1-21; dexamethasone $40 \mathrm{mg} / \mathrm{day}$, days $1,8,15$, and 22) were started after a clinical recurrence at the 26th month of follow-up. The patient was in R-ISS stage 3 at the time of relapse (FISH with $17 p$ was $12 \%$ positive). Ixazomib
(4 mg/day, days 1,8 , and 15 ) was added to the treatment due to stable disease findings at the $3^{\text {rd }}$ month of evaluation. On the $13^{\text {th }}$ day of treatment, he presented with a high fever $\left(38.7^{\circ} \mathrm{C}\right)$ and sudden, painful, 1- to 2-cm-diameter indurated, erythematous, papular lesions on the front and back of the neck (Figure 1). Laboratory tests showed a white blood cell count of $2.1 \times 10^{9} / \mathrm{L}$, neutrophil cell count of $1.4 \times 10^{9} / \mathrm{L}$, hemoglobin concentration of $8.9 \mathrm{~g} / \mathrm{dL}$, and platelet count of $37 \times 10^{9} / \mathrm{L}$. Skin biopsy revealed marked perivascular neutrophilic inflammatory infiltration in the dermis, consistent with Sweet syndrome. While arthralgia and myalgia were present, as seen in cases of Sweet syndrome, no ocular inflammation, headaches, or oral or genital lesions appeared. There was no granulocyte colonystimulating factor usage, the antinuclear antibody (ANA) test was negative, and no signs of infection were detected. Ixazomib was stopped. Triamcinolone acetonide (0.1\%) was applied locally. The lesions disappeared significantly by the $10^{\text {th }}$ day. One of the common side effects of ixazomib has been reported 